\title{
Spectrophotometric Determination of Ascorbic Acid in
}

\section{Aqueous Solutions}

\author{
Dhuha Hashem Fadhel \\ Department of Chemistry, College of Science, Al-Nahrain University, Baghdad-Iraq.
}

\begin{abstract}
Anew spectrophotometeric method for determination of ascorbic acid(A.A) in aqueous solutions depending on its ability to reduce the colors of permanganate at $(530 \mathrm{~nm})$ and dichromate at $(350 \mathrm{~nm})$. The optimum conditions such as best concentration of reactant and order of addition were studied to get the highest sensitivity $(\varepsilon=2355.70$ and 3094.75$) \mathrm{L}_{\mathrm{mol}}{ }^{-1} . \mathrm{cm}^{-1}$ with wide range of calibration curves (1-16) and (2-90) ppm good repeatability (RSD\% 0.73 and 1.49), the recovery $\%\left(100.20\right.$ and 99.42), $\mathrm{E}_{\mathrm{rel}} \%$ (-0.20 and 0.58) for gave, Pharmaceutically prepared tablets were measured with the new technique using Standard Addition Method given a very good recovery \% (101.25 and 98.75) with a small $\mathrm{E}_{\mathrm{rel}} \%(-1.25$ and 1.25$)$.
\end{abstract}

Keywords: ascorbic acid, UV/VIS spectrophotometry, pharmaceutical analysis.

\section{Introduction}

Ascorbic acid (also called Vitamin C) is a naturally occurring organic compound with antioxidant properties. It is a white solid but impure samples can appear yellowish. Ascorbic acid is one form ("vitamer") of vitamin $\mathrm{C}$. The name is derived from $a$ (meaning "no") and scorbutus (scurvy), the disease caused by a deficiency of vitamin C. Being derived from glucose, many animals are able to produce it, but humans require it as a nutritional supplement [1].

The chemical formula is $(\mathrm{R})-5-((\mathrm{S})-1,2-$ dihydroxyethyl)-3,4-dihydroxyfuran-2(5H)one, molar mass $176.12 \mathrm{~g}$ mol-1, Density $1.65 \mathrm{~g} / \mathrm{cm}^{3}$, melting point $190-192{ }^{\circ} \mathrm{C}$, with solubility in water about $33 \mathrm{~g} / 100 \mathrm{~mL}$.

It is a water-soluble vitamin which can be found in many biological systems and foodstuffs (fresh vegetables and fruits, namely, citrus). Ascorbic acid plays an important role in collagen biosynthesis, iron absorption, and immune response activation and is involved in wound healing and osteogenesis. It also acts as a powerful antioxidant which fights against free-radical induced diseases [2-6].

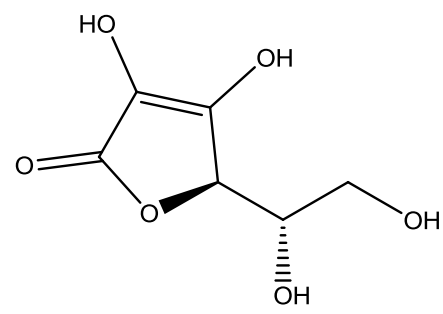

ascorbic acid
Most importantly, ascorbic acid is a mild reducing agent. For this reason, it degrades upon exposure to oxygen, especially in the presence of metal ions and light. It can be oxidized by one electron to a radical state or doubly oxidized to the stable form called dehydroascorbic acid.

Many analytical methods can be used for ascorbic acid determination. Classic (conventional) techniques are represented by volumetric methods - titration with an oxidant solution such as dichlorophenol indophenol (DCPIP) [7,8], potassium iodate[9], or bromate [10]. Volumetric techniques can suffer from lack of specificity [11] which limits their use to samples not containing other reducing agents.

Güçlï et al. [12] have proposed a spectrophotometric method based on ascorbic acid oxidation to dehydroascorbic acid, by using the $\mathrm{Cu}(\mathrm{II})$-neocuproine complex, which is reduced to $\mathrm{Cu}(\mathrm{I})$-bis(neocuproine), the absorbance of the latter being determined at $450 \mathrm{~nm}$. Other optical methods for vitamin C estimation include spectrophotometrical determination of iodine reacted with ascorbic acid [13] and chemiluminescence [14].

Liquid chromatography is a successful method for vitamin $\mathrm{C}$ determination when selectivity and specificity are concerned [1517]. HPLC with electrochemical detection has turned out to be a selective and sensitive 
method for ascorbic acid assessment in foodstuffs and biological fluids [18-20].

A potentiometric biosensor [21] for ascorbic acid was made by ascorbate oxidase immobilization in a polymeric matrix, fixed on a graphite-epoxy composite electrode.

Amperometric biosensors were obtained by ascorbate oxidase immobilization on a nylon net [22] or on a collagen membrane, using a Clark oxygen electrode as transducer [23]. Vitamin $\mathrm{C}$ analysis was also performed by using a glassy carbon working electrode as transducer incorporated in a flow system [24]. Ascorbic and uric acids were determined by coupling an amperometric technique with flow analysis [25]. Voltammetric and amperometric measurements were performed in a flow cell, using gold microelectrodes on which $\mathrm{Pd}$ was electrochemically deposited.

\section{Experimental}

Apparatuses, chemicals and reagents:

- UV/VIS spectrophotomitric (Shimadzo, 1650PC, Japan) with $1 \mathrm{~cm}$ matched quartz cell

- Chemicals: Ascorbic Acid (analytical grade), potassium dichromate (99.9\% purity) and potassium permanganate (99.5\% purity) was obtained from BDH.

- Vitamin C tablets was obtained from pharmaceutically prepared tablets

- German Vitamin C, T and D Pharma GmbH, GERMANY.

o Cetavit 500mg Vitamine C, ALSHAHBA LABS. ALEPPO SYREIA.

\section{Preparation of standard solutions}

A standard solution of $100 \mathrm{ppm}$ ascorbic acid was freshly prepared by dissolving $0.01 \mathrm{~g}$ of ascorbic acid and diluted to $100 \mathrm{~mL}$ with distilled water.

A $100 \mathrm{ml}$ of $\mathrm{KMnO}_{4}$ Standard solution (100 ppm) was prepared by dissolving $0.01 \mathrm{~g}$ $\mathrm{KMnO}_{4}$ in $5 \mathrm{M} \mathrm{H} \mathrm{H}_{2} \mathrm{SO}_{4}$ and completed with distilled water, and in a dark place.

A 500 ppm $\mathrm{K}_{2} \mathrm{Cr}_{2} \mathrm{O}_{7}$ in $100 \mathrm{~mL}$ Standard solution, was prepared by dissolving $0.05 \mathrm{~g}$ $\mathrm{K}_{2} \mathrm{Cr}_{2} \mathrm{O}_{7}$ in $5 \mathrm{M} \mathrm{H}_{2} \mathrm{SO}_{4}$ and completed with distilled water.

\section{Preparation of Mixtures}

For 5 different $(25 \mathrm{~mL})$ volumetric flask a 40ppm $\mathrm{KMnO}_{4}$ was added, then 1, 4, 8, 12 and $16 \mathrm{ppm}$ ascorbic acid was added for each respectively. The absorbency of mixture were measured using UV-Vis spectrophotometer at $530 \mathrm{~nm}$.

For 10 different $(25 \mathrm{~mL})$ volumetric flask a $100 \mathrm{ppm} \mathrm{K}_{2} \mathrm{Cr}_{2} \mathrm{O}_{7}$ was added, then 2, 10, 20, $30,40,50,60,70,80,90$ ppmascorbic acid was added for each respectively. The mixtures were measured at $(350 \mathrm{~nm})$ using UV-Vis spectrophotometer.

\section{Results and Discussion}

Procedure of appropriate wave lengths:

The absorbance of each solution was measured from (450-600nm) for permanganate and from (300-600nm) for dichromate in presence of different concentrations of A.A, the spectra obtained were represented in Fig.(1) and Fig. (2).

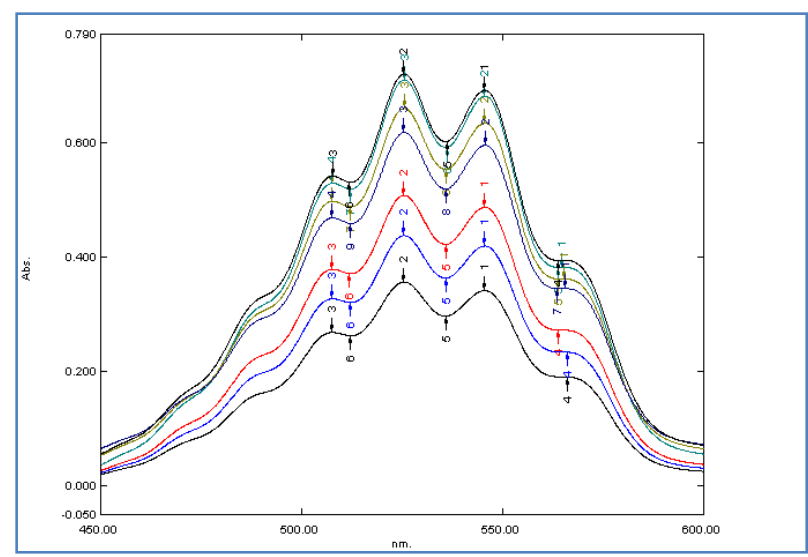

Fig. (1) Spectra of $\mathrm{KMnO}_{4}$ in the presence of (1- 16 ppm) A.A.

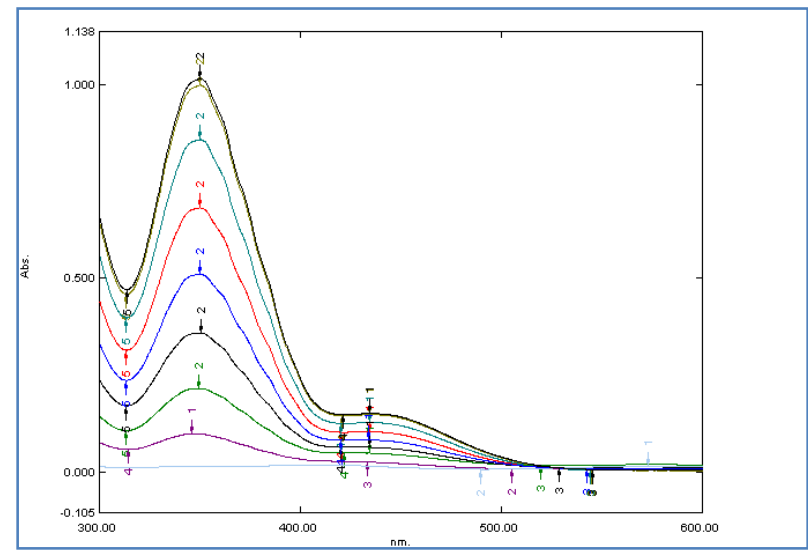

Fig. (2) Spectra of $\mathrm{K}_{2} \mathrm{Cr}_{2} \mathrm{O}_{7}$ in the presence of (2- 90 ppm) A.A. 


\section{Procedure of the optimum conditions}

The best absorption of $\mathrm{KMnO}_{4}$ was in the concentration of 40ppm while for the $\mathrm{K}_{2} \mathrm{Cr}_{2} \mathrm{O}_{7}$ it was $100 \mathrm{ppm}$. See Fig. (3) (the absorption of different concentrations of $\mathrm{KMnO}_{4}$ shows that the 40ppm is the highest peak), see also Fig.(4) (the absorption of different concentrations of $\mathrm{K}_{2} \mathrm{Cr}_{2} \mathrm{O}_{7}$ shows that the $100 \mathrm{ppm}$ is the highest peak).

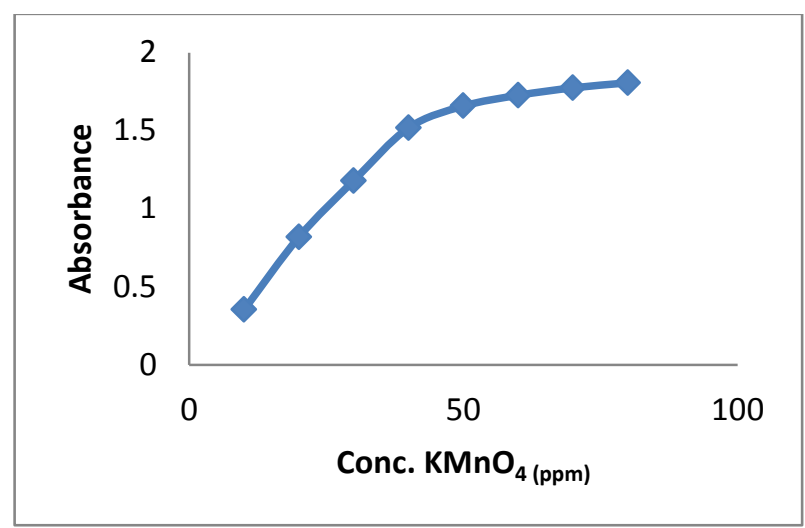

Fig. (3) The best absorbance at different concentrations of $\mathrm{KMnO}_{4}$.

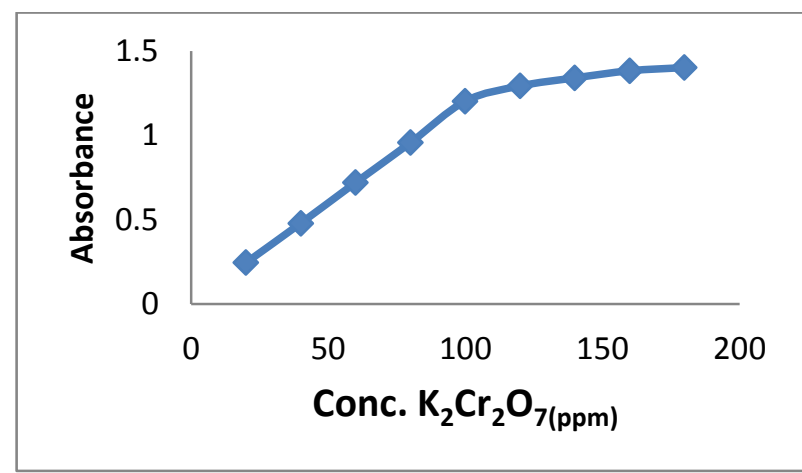

Fig. (4) The best absorbance at different concentrations of $\mathrm{K}_{2} \mathrm{Cr}_{2} \mathrm{O}_{7}$.

\section{The effect of order of addition}

In order to have high sensitivity and a linear range for the calibration curve, the effect of the order of addition of A.A. to $\mathrm{KMnO}_{4}$ and $\mathrm{K}_{2} \mathrm{Cr}_{2} \mathrm{O}_{7}$ respectively was studied as shown in Table (1) :

Table (1)

Shows the order of addition of A.A. and reagents.

\begin{tabular}{|c||c||c||}
\hline Order no. & $\begin{array}{c}\text { Reaction } \\
\text { component }\end{array}$ & absorbance \\
\hline \hline I & $\mathrm{KMnO}_{4}+\mathrm{A} . \mathrm{A}$. & 0.418 \\
\hline \hline II & $\mathrm{A} . \mathrm{A} .+\mathrm{KMnO}_{4}$ & 0.337 \\
\hline \hline I & $\mathrm{K}_{2} \mathrm{Cr}_{2} \mathrm{O}_{7}+\mathrm{A} . \mathrm{A}$. & 0.523 \\
\hline \hline II & $\mathrm{A} . \mathrm{A} .+\mathrm{K}_{2} \mathrm{Cr}_{2} \mathrm{O}_{7}$ & 0.438 \\
\hline
\end{tabular}

Employing the conditions described in the procedure, a linear calibration graph of ascorbic acid is obtained from difference between absorbance of zero conc. (blank) of $\mathrm{KMnO}_{4}$ and $\mathrm{K}_{2} \mathrm{Cr}_{2} \mathrm{O}_{7}$ respectively and the absorbance of different concentrations from pure ascorbic acid combined with the same mixture. Fig.(5) and (6) which shows that beers law is obeyed over the concentration range (1-16) and (2-90) ppm for $\left(\mathrm{KMnO}_{4}+\right.$ A.A. $) \quad \& \quad\left(\mathrm{~K}_{2} \mathrm{Cr}_{2} \mathrm{O}_{7}+\right.$ A.A. $)$ respectively. With correlation coefficient 0.9975 and 0.9980 while the molar absorptivies 2355.7 and $3094.8 \mathrm{~L} \mathrm{~mol}^{-1} \mathrm{~cm}^{-1}$ for $\mathrm{KMnO}_{4}$ and $\mathrm{K}_{2} \mathrm{Cr}_{2} \mathrm{O}_{7}$ respectively.

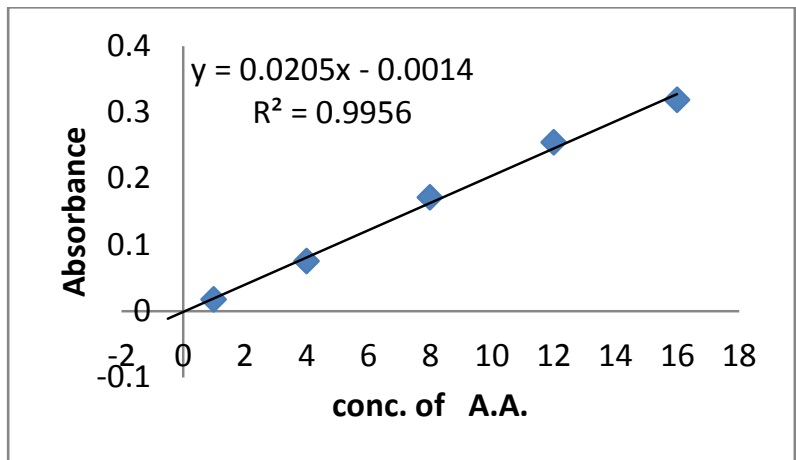

Fig.(5) Calibration curve of permanganate with A.A.

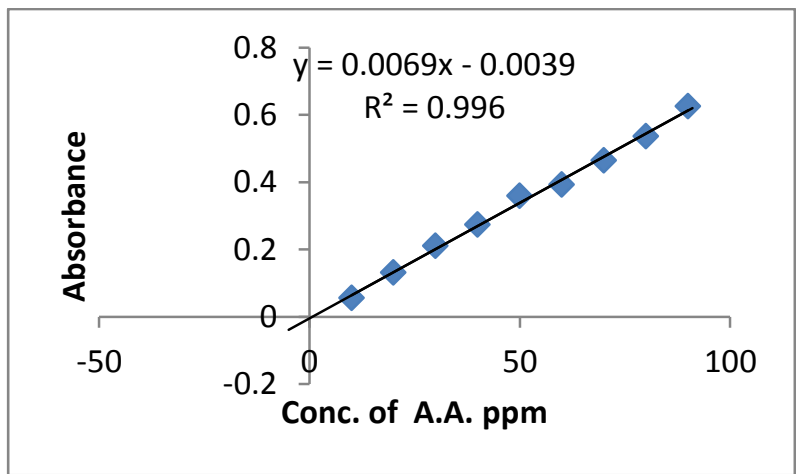

Fig. (6) Calibration curve of dichromate with A.A.

The absorbance concentration plots for the proposed methods were found to be linear over the range of (1-16) ppm \& (2-90) ppm for A.A. with and A.A. withdichromate respectively. 
Table (2)

Comparism of linear range for the two methods.

\begin{tabular}{|c|c|c|}
\hline Parameters & Value $\left(\mathrm{KMnO}_{4}\right)$ & Value $\left(\mathrm{K}_{2} \mathrm{Cr}_{2} \mathrm{O}_{7}\right)$ \\
\hline Linearity range (ppm) & $1-16$ & $2-90$ \\
\hline Regression equation & $y=0.020 x-0.001$ & $y=0.006 x-0.003$ \\
\hline Slop & 0.02 & '0.006 \\
\hline intercept & -0.001 & -0.003 \\
\hline Correlation coefficient (r) & 0.9975 & 0.9980 \\
\hline Linearity $\left(\% \mathrm{r}^{2}\right)$ & 0.9950 & 0.9960 \\
\hline Molar absorpitivity $\left(\mathrm{L} \cdot \mathrm{mol}^{-1} \cdot \mathrm{cm}^{-1}\right)$ & 2355.70 & 3094.75 \\
\hline
\end{tabular}

Determination of the pure A.A. was carried out through replicate analysis of 5 times for 10 ppm manganese +A.A. \& 80 ppm dichromate + A.A. the results of recovery $\%$, RSD\% (Relative Standard Deviation), $\mathrm{E}_{\text {rel }} \%$ (error relative) and C.L. (Confidence Limit at 95\% confidence level and 4 degrees of freedom $(\mathrm{t}=2.78)$ ) are shown in Table (3) below:

Table (3)

Accuracy and precision results for the proposed methods ${ }^{*}$.

\begin{tabular}{|c|c|c|c|c|c|c|}
\hline \multirow{2}{*}{ compounds } & \multicolumn{2}{|c|}{ Amount (ppm) of A.A } & \multirow{2}{*}{$\% R S D$} & \multirow{2}{*}{ \%Rec. } & \multirow{2}{*}{$\% E_{r e l .}$} & \multirow{2}{*}{ C.L. } \\
\hline & taken & found & & & & \\
\hline $\mathrm{KMnO}_{4}+$ A.A. & 10 & $10.02 \pm 0.0032$ & 0.73 & 100.2 & -0.2 & $10.02 \pm 0.00399$ \\
\hline $\mathrm{K}_{2} \mathrm{Cr}_{2} \mathrm{O}_{7}+$ A.A. & 80 & $79.53 \pm 0.0087$ & 1.49 & 99.42 & 0.58 & $79.53 \pm 0.01086$ \\
\hline
\end{tabular}

*mean foe 5 independent analysis

\section{Drug Analysis}

Two pharmaceuticallyprepared drugs were tested using Standard Addition Method (SAM), the results of the method are shown in
Fig. $(7 \& 8)$ and summary of results is shown in Table (4) below:

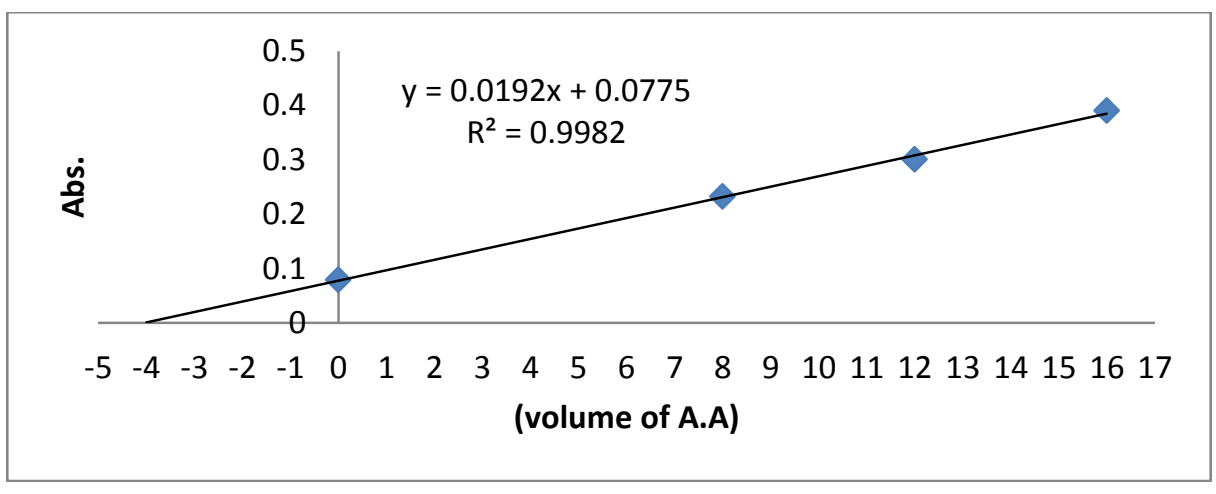

Fig. (7) Standard Addition curve for the determination of (cetavit (Vitamin C)) using permanganate. 


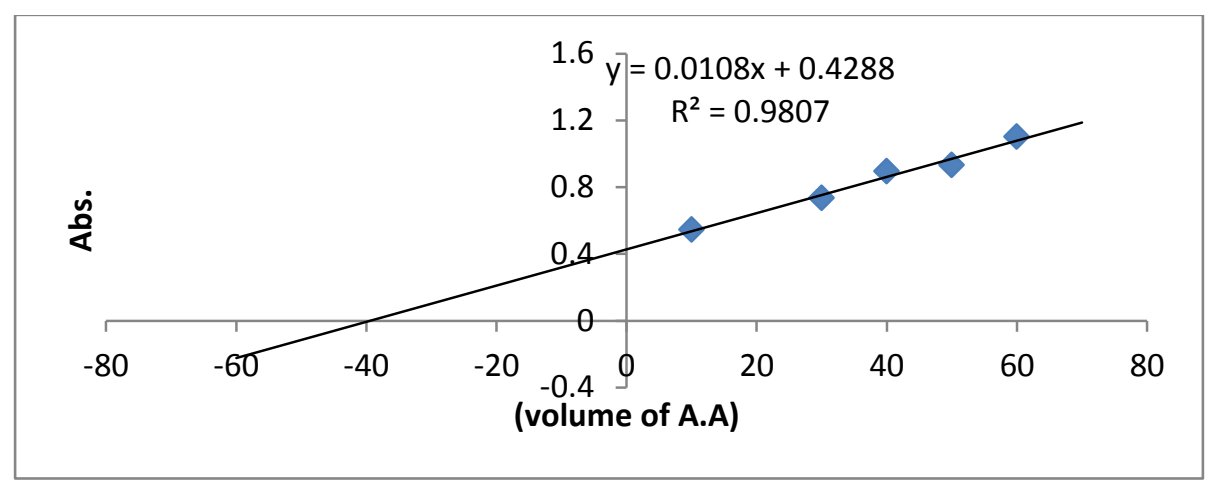

Fig. (8) Standard Addition curve for the determination of (German Vitamin C) using dichromate.

Table (4)

Summary of linearity studies of A.A. in pharmaceutically prepared tablets using SAM.

\begin{tabular}{|c||c|c|c|c|c||}
\hline Drugs & $\begin{array}{c}\text { Regression } \\
\text { equation }\end{array}$ & Slop & Intercept & Len. & $\begin{array}{c}\text { Correlation } \\
\text { coefficient } \\
(\boldsymbol{r})\end{array}$ \\
\hline \hline CetavitVit C & $\mathrm{y}=0.019 \mathrm{x}+0.077$ & 0.019 & 0.077 & 99.80 & 0.9989 \\
\hline \hline German Vit C & $\mathrm{y}=0.010 \mathrm{x}+0.428$ & 0.010 & 0.428 & 98.00 & 0.9899 \\
\hline
\end{tabular}

The results are reported in Table (5) as can be seen from it that the recovery $\%$ and $\mathrm{E}_{\text {rel }} \%$. The results were reliable and accurate.

\begin{tabular}{|c||c|c||c|c||}
\hline Drugs & $\begin{array}{c}\text { Amount added } \\
\text { ppm }\end{array}$ & $\begin{array}{c}\text { Amount } \\
\text { recovered ppm }\end{array}$ & Recovery \% & $\boldsymbol{E}_{\text {rel }} \%$ \\
\hline \hline CetavitVit C & 4 & 4.05 & 101.25 & 1.25 \\
\hline \hline German Vit C & 40 & 39.50 & $98.75 \%$ & 1.25 \\
\hline \hline
\end{tabular}

\section{References}

[1] PadayattyS. J., Sun H., Wang Y., Riordan H.D., Hewitt S.M., Katz A., R.A. Wesley, and Levine M., "Vitamin C pharmacokinetics: implications for oral and intravenous use," Ann Intern Med, vol. 140, pp. 533-537, 2004.

[2] Bhagavan N. V., Medical Biochemistry, Elsevier, Amsterdam, The Netherlands, 4th edition, 2001.

[3] Cathcart R. F., "A unique function for ascorbate," Medical Hypotheses, vol. 35, no. 1, pp. 32-37, 1991.

[4] Mohora M., BiochimieMedicală, EdituraNiculescu, Bucuresti, Romania, 2006.
[5] Şerban M., Tămaş V., and Cotruţ V., BiochimieMedicalăVeterinară, EdituraDidacticasiPedagogica, Bucuresti, Romania, 1981.

[6] Fox B. A. and Cameron A. G., Food Science, Nutrition and Health, Edward Arnold, London, UK, 5th edition, 1989.

[7] Şerban M., CâmpeanuGh., and Ionescu E., Metode de LaboratorînBiochimiaAnimală, EdituraDidacticasiPedagogica, Bucuresti, Romania, 1993.

[8] Papuc C., Pop A., and Şerban M., MetodeAnalitice in BiochimiaVeterinara, EdituraPrintech, Bucuresti, Romania, 2001.

[9] Balan D., Pele M., Artimon M., and Luta G., "Bioactive compounds in sea buckthorn fruits and in some products 
obtained by their processing," Revue de Cytologie et de BiologieVégétales-Le Botaniste, vol. 28, pp. 364-368, 2005.

[10] Matei N., Magearu V., Birghilă S., and. Dobrinaş S., "The determination of vitamin $\mathrm{C}$ from sweet cherries and cherries," Revista de Chimie, vol. 55, no. 5, pp. 294-296, 2004.

[11] O'Connel P.J., Gormally C ., Pravda M. and Guilbault G.G. , "Development of an amperometric L-ascorbic acid (vitamin C) sensor based on electropolymerised aniline for pharmaceutical and food analysis," AnalyticaChimicaActa, vol. 431, no. 2, pp. 239-247, 2001.

[12] Güçlü K., Sözgen K., Tütem E., Özyürek M., and Apak R., "Spectrophotometric determination of ascorbic acid using copper(II)-neocuproine reagent in beverages and pharmaceuticals," Talanta, vol. 65, no. 5, pp. 1226-1232, 2005.

[13] Danet A. F., David V., and Oancea M., "Dispozitiv de analiza in flux cu injectarehidrodinamica.

Determinareavitaminei C," Revista de Chimie, vol. 45, no. 11, pp. 1000-1006, 1994.

[14] Danet A.F., Badea M., and Aboul-Enein H.Y., "Flow injection system with chemiluminometric detection for enzymatic determination of ascorbic acid," Luminescence, vol. 15, no. 5, pp. 305-309, 2000.

[15] Oliveira E .J. and Watson D. G., "Chromatographic techniques for the determination of putative dietary anticancer compounds in biological fluids," Journal of Chromatography B, vol. 764, no. 1-2, pp. 3-25, 2001.

[16] KallM. A.and Andersen C., "Improved method for simultaneous determination of ascorbic acid and dehydroascorbic acid, isoascorbic acid and dehydroisoascorbic acid in food and biological samples," Journal of Chromatography B, vol. 730, no. 1, pp. 101-111, 1999.

[17] Wase H. I. and Ono I. , "Determination of ascorbic acid in food by column liquid chromatography with electrochemical detection using eluent for pre-run sample stabilization," Journal of Chromatography $A$, vol. 806, no. 2, pp. 361-364, 1998.
[18] IWase H., "Use of nucleic acids in the mobile phase for the determination of ascorbic acid in foods by highperformance liquid chromatography with electrochemical detection," Journal of Chromatography A, vol. 881, no. 1-2, pp. 327-330, 2000.

[19] Rizzolo A. , Brambilla A., Valsecchi S., and. Eccher-Zerbini P., "Evaluation of sampling and extraction procedures for the analysis of ascorbic acid from pear fruit tissue," Food Chemistry, vol. 77, no. 2, pp. 257-262, 2002.

[20] Rodríguez-Comesaña M., García-Falcón M. S., and Simal-Gándara J., "Control of nutritional labels in beverages with added vitamins: screening of $\beta$-carotene and ascorbic acid contents," Food Chemistry, vol. 79, no. 2, pp. 141-144, 2002.

[21] Fernandes J. C. B. , L. T. Kubota, and de Oliveira Neto G., "Potentiometric biosensor for L-ascorbic acid based on ascorbate oxidase of natural source immobilized on ethylene-vinylacetate membrane," AnalyticaChimicaActa, vol. 385, no. 1-3, pp. 3-12, 1999.

[22] Tomita N. I., Manzoli A., Fertonani F. L., and Yamanaka H., "Amperometric biosensor for ascorbic acid," EcléticaQuímica, vol. 30, no. 2, pp. 37-43, 2005.

[23] Matsumoto K., Yamada K., and Osajima Y., "Ascorbate electrode for determination of L-ascorbic acid in food," Analytical Chemistry, vol. 53, no. 13, pp. 1974-1979, 1981.

[24] Greenway G .M. and Ongomo P., "Determination of L-ascorbic acid in fruit and vegetable juices by flow injection with immobilisedascorbate oxidase," Analyst, vol. 115, no. 10, pp. 1297-1299, 1990.

[25] Matos R. C., Augelli M. A., Lago C. L., and Angnes L., "Flow injection analysisamperometric determination of ascorbic and uric acids in urine using arrays of gold microelectrodes modified by electrodeposition of palladium," AnalyticaChimicaActa, vol. 404, no. 1, pp. 151-157, 2000. 


\section{الخلاصة}

تم استخدام طريقة طيفية لتقدير حامض الاسكوربيك في

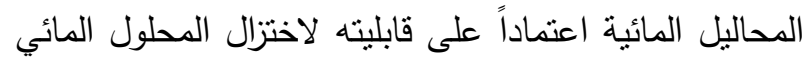

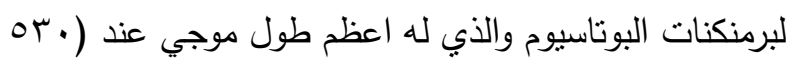

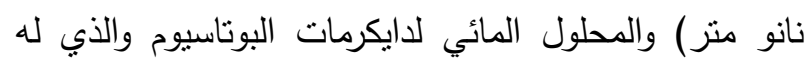

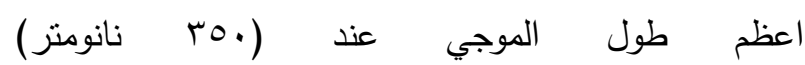

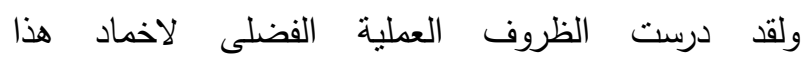

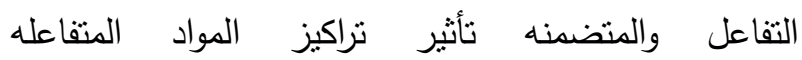
وتأثير ترتيب الأضافة للحصول على حساسية عالية

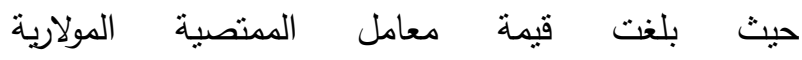
(2355.7 و 3094.75) لتر . مول-'. سم-' على التوالي

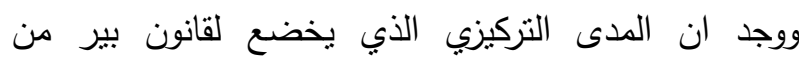
(1-16) ومن (90-2) مايكروغرام.مل'- . اما التكرارية للنتائج

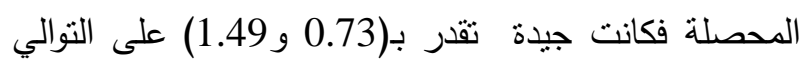

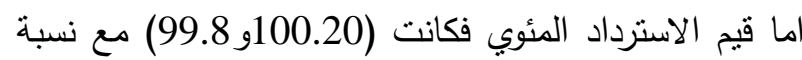

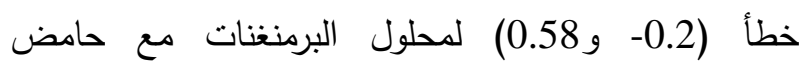
الأسكوربيك ومحلول الدايكرومات مع حامض الأسكوربيك

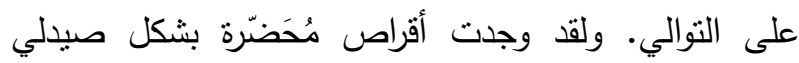
قيست بالتقنية الجديدة وقد اعطت قيم جيده جدا للأسترداد المئوي (101.25 و 98.75) مع نسبة خطأ قليلة جداً (. 1.25 